\title{
ステンレス線を用いた限流ヒューズの基礎特性の検討
}

\section{Investigation of Basic Characteristics of Current-limiting Fuse Using Stainless Steel Wire}

\author{
湯地敏史 $* * *$ ・大坪昌久***・本田親久***・稲葉 次 紀****・赤塚 洋***** \\ Toshifumi YUJI, Masahisa OTSUBO, Chikahisa HONDA, Tsuginori INABA and Hiroshi AKATSUKA
}

(Received October 10, 2006)

\begin{abstract}
Recently, owing to the high demand and high dependence on electric power, the reliability of the distribution voltage of electric power systems has become more important. $22 \mathrm{kV}$ high voltage cutout fuses have been used widely, but some breaking accidents occurred because of pollution / contamination of bushings. With the increase in contaminants on bushings, the electric fields on the fuse element surface rise to a critical level and trigger corona discharge. The fuse element material which is more resistant to corona discharge compared to Ag element is desired. A new type current-limiting fuse made of stainless steel wire of low cost and simple design has been developed. Some characteristic tests including : breaking test with a high surge current and noise intensity when a voltage was applied. It was confirmed that the new type fuse possesses similar performance characteristics as compared with the Ag element using model fuse.
\end{abstract}

Key Words: Large current breaking characteristics, Stainless steel wire, Arc current, High-voltage cutout, Current-limiting fuse

\section{1. まえがき}

電力需要増大に伴う短絡容量増大と供給信頼度の向上に 対処するため, 配電用開閉保護装置の大電流における遮断 性能の向上と特性の検証が要望されており ${ }^{1)}$, 高圧カット アウトヒューズもこれら電力需要に伴い設置台数が漸増し ている。

沿岸地区において，平成 7 年頃 $22 \mathrm{kV}$ 級高圧カットアウ 卜用限流ヒューズの溶断事故が多発した ${ }^{2)}$ 。これらの事故 要因として, これまでの著者らの研究結果より, 例えば 高圧カットアウト碍管が污損した場合に碍管とヒューズエ レメント部間に高電界が生じて, ヒューズエレメント部に コロナ放電が発生し, 通常のヒューズに使用されている銀 (以下， Ag）エレメントが熱劣化により溶断事故を引き起 こす要因となることが報告されている3) ${ }^{4)}$ ○こで, これ らの熱劣化によるヒューズ溶断事故を未然に防ぐヒューズ

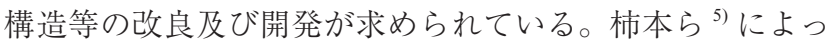

て，ステンレス線を用いた高圧カットアウト用ヒューズの 開発が行われているが, 構造が放出型形状のためヒューズ 溶断時の周囲への溶断音や消弧チューブから放出される分 解ガス ${ }^{6}$ の問題があり，生活環境への影響も懸念される。

そこで本研究では，現在使用されている Agエレメント を用いた限流ヒューズと比較して，コロナ放電に耐性を 持つステンレス線（SUS304）をエレメント部に使用して, ヒューズ溶断時に溶断音を抑え及び容易な構造で且つ安価 な $22 \mathrm{kV}$ 級高圧カットアウト用限流ヒューズの開発を目的 としている ${ }^{7)^{8}}$ 。

本論文においては，現在使用されている $\mathrm{Ag}$ エレメント をステンレス線に代えてエレメント部の構造を新たに設計 した $22 \mathrm{kV}$ 級高圧カットアウト用限流ヒューズ（以下，模 擬ヒューズ）を試作し，ヒューズの特性試験の 1 つである 振動性インパルス大電流遮断特性試験（以下，遮断試験） を行った。ここで提案した中央部に細線箇所を持つ模擬 ヒューズの振動性インパルス大電流遮断特性は, ヒューズ

* 東京工業大学大学院 理工学研究科 原子核工学専攻（

**広島商船高等専門学校 電子制御工学科（† 725-0231 広島県豊田郡大崎上島町東野 4272 番地 1）

*** 宮崎大学工学部 電気電子工学科（＝ 889-2192＼cjkstart宮崎県宮崎市学園木花台西 1-1-1）

* * * * 中央大学 理工学部 電気電子情報通信工学科（

*****東京工業大学 原子炉工学研究所（干 152-8550 東京都目黒区大岡山 2-12-1） 
エレメント部に Ag エレメントを使用した場合と比較して， 同等の遮断特性が得られることが確認できた。そこで, Ag エレメントに変わるステンレス線の遮断特性について検討 した結果を報告する。

\section{2. 計測装置及び方法}

遮断試験は, 復旧作業の困難な本線部分でのフラッシ オーバを防止し, 変圧器周辺部で雷サージフラッシオー バを起こさせ，続いて流れる短絡電流を高圧カットアウト ヒューズで確実に遮断させるための遮断性能を検討する試 験である ${ }^{9)}$ 。図 1 に遮断特性試験回路を示す。使用した電 源ならびに測定装置は，アレス夕の電圧及び電流特性試験 用の衝撃電圧電流発生装置 (東京変圧器(株製) である。遮 断試験においては, 避雷素子の代わりに模擬ヒューズを設 置し, 端子電圧及び電流波形をオシロスコープ (Yokogawa

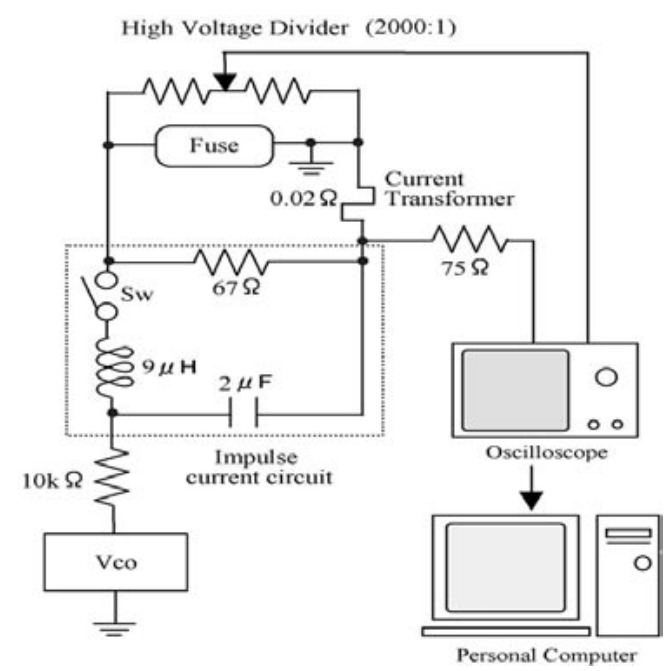

Fig.1 Experimental circuit for large current breaking test.

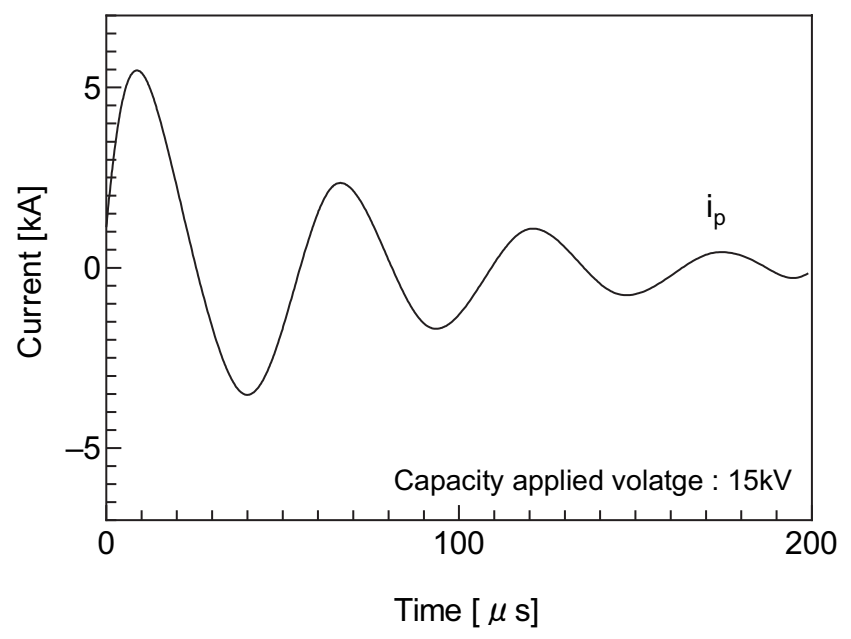

Fig.2 Peculiar current waveform.
製；型式 DL1540）で計測して端子電圧及び電流特性を調 ベた。図 2 にコンデンサの充電電圧（Vco）が $15 \mathrm{kV}$ の きの固有電流（ip）波形を示す。遮断試験においては 2 種 類の構造の模擬ヒューズを使用し，それぞれを図３及び図 4 に示す。図 3 に示すように 1 本のステンレス線を大気中 に水平・直線状に設置した構造の模擬ヒューズを TYPE (1) と呼ぶ。また，図4には 2 本のステンレス線をヒューズ エレメントとして，そのうちヒューズのエレメント中央部 を 1 本で構成しており中央部で模擬ヒューズが確実に溶断 するためにギャップ (d) を設けている構造の模擬ヒューズ (TYPE(2)）を示す。このギャップについては, 熱伝導方程 式等 ${ }^{10)}$ を十分考慮した上で構造を検討している。TYPE(2) の場合においては, ヒューズエレメント中央部には, ヒュー ズ溶断時に発生するアークを消弧する目的として ${ }^{11)}$, 透明 な消弧チューブ（Poly Tetra Fluoro Ethylene;PTFE）:内径（以 下， $\phi \mathrm{p} ） 0.5 \mathrm{~mm}$ 取り付けアクリルパイプ内に消弧砂を封 入した。また, 各構造のヒューズ遮断試験の際に模擬ヒュー ズ設置箇所から直線方向に $1 \mathrm{~m}$ 離れた位置で騒音計（リオ ン製；NA-17）により模擬ヒューズ溶断時の最大騒音を測 定すると共に，Agエレメント及びステンレス線を用いた模 擬ヒューズ（TYPE(2)）においてヒューズエレメントの溶 断メカニズム過程を検討するためにイメージコンバータカ メラ（Hadland 社製；IMECON468）を用いてヒューズ溶断

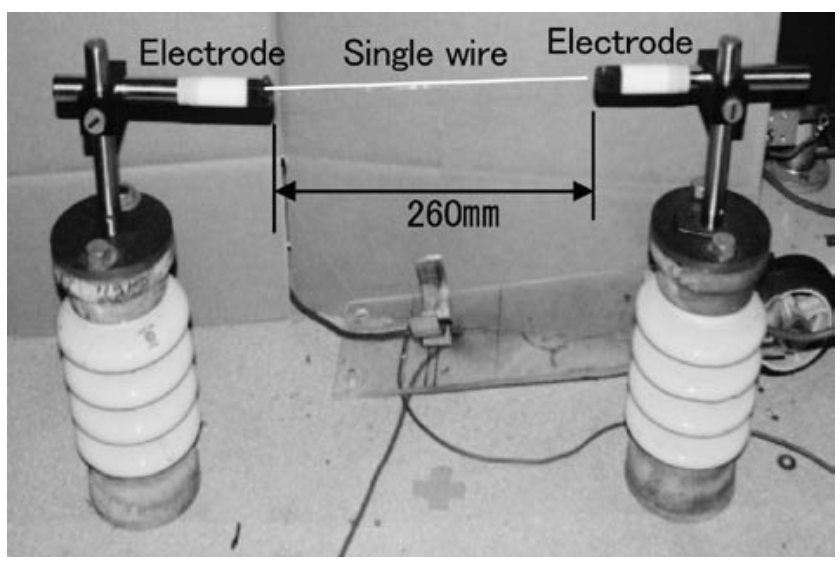

Fig.3 Trial fuse (TYPE(1))

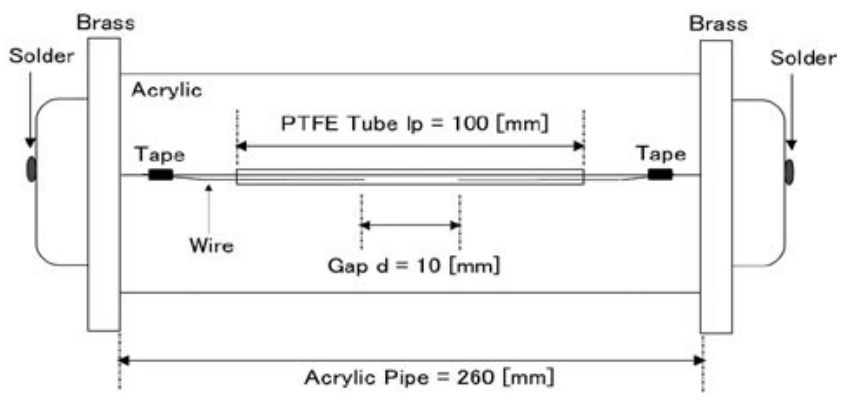

Fig.4 Trial fuse (TYPE(2)) 


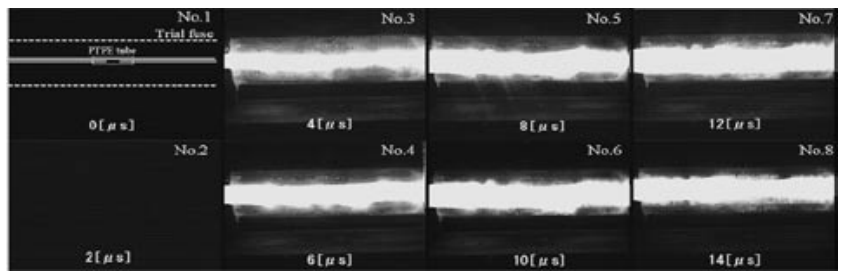

Fig.5 Framing photos in fusion test of trial fuse by Image converter camera (Ag element).

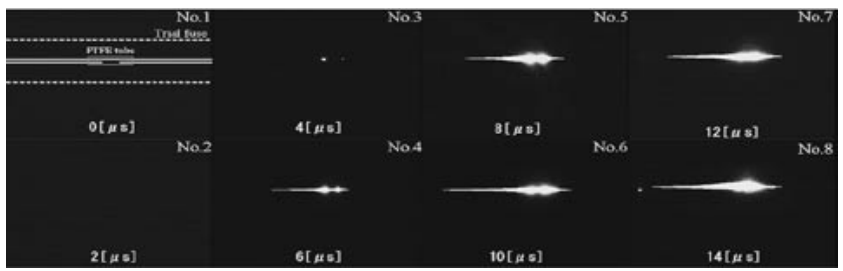

Fig.6 Framing photos in fusion test of trial fuse by Image converter camera (Stainless steal wire)

開始から $2 \mu \mathrm{s}$ 間隔及び 8 コマ（休止 $5 \mathrm{~ns}$ ) の模擬ヒューズ エレメント部溶断の際の各金属線の発光を撮影した。

\section{3. 実験的検討及び考察}

\section{1 ヒューズエレメントの溶断過程}

図 5 及び図 6 にTYPE (2)に扔いて印加電圧 $30 \mathrm{kV}$ ，エレ メント部に $\mathrm{Ag}$ エレメント直径（以下， $\phi \mathrm{s}$ ） $0.1 \mathrm{~mm}$ 及びス テンレス線の $\phi \mathrm{s}=0.2 \mathrm{~mm}$ 用いて, 消弧チューブの形状は $\phi \mathrm{p}=1.0 \mathrm{~mm}$ ，消弧チューブ長さ（以下， $1 \mathrm{p} ） 100 \mathrm{~mm}$ を使用 した際のイメージコンバータカメラによるヒューズ溶断時 の撮影写真を示す。2つのヒューズエレメント材料の特性 は，抵抗值が異なるが ${ }^{22}$, 模擬ヒューズのエレメント部の 構造を統一して特性試験を行った。図 5 において発光が全 体的に広がって見えるのに対して，図６に扔いては，模擬 ヒューズのエレメント中央部では, 強い発光が顕著に確認 できる。ヒューズエレメント中央部のギャップは, 確実に 中央部にて溶断するための機能に寄与していることが確認 できた。 $\mathrm{Ag} に$ にいては, 材質の違いに扔いて突発的な電 流を通じると断熱的な温度上昇を生じて ${ }^{13}$ 全体的な発光と なったと予想される。

また，撮影写真と同時に計測した電圧及び電流波形を図 7 に示す。同図 (a) に扔いて $\mathrm{Ag}$ エレメントを使用した模擬 ヒューズでは, 通電開始後約 $6 \mu \mathrm{s}$ で電流波形のピーク值が 約 $4.5 \mathrm{kA}$ で溶断に至っている。通電開始から約 $40 \mu \mathrm{s}$ でアー ク電流は約 $300 \mathrm{~A}$ であった。ステンレス線を使用した模擬 ヒューズに打いては, 同図 (b) より通電開始後 $7 \mu \mathrm{s}$, 電流 波形のピーク值が約 $2.8 \mathrm{kA}$ で溶断に至っており約 $22 \mu \mathrm{s}$ の

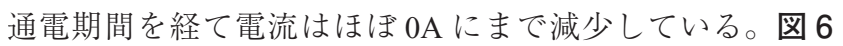
よりNo.5（図7(b)に押いて(5)）は, 通電開始後約 $8 \mu \mathrm{s}$ 経

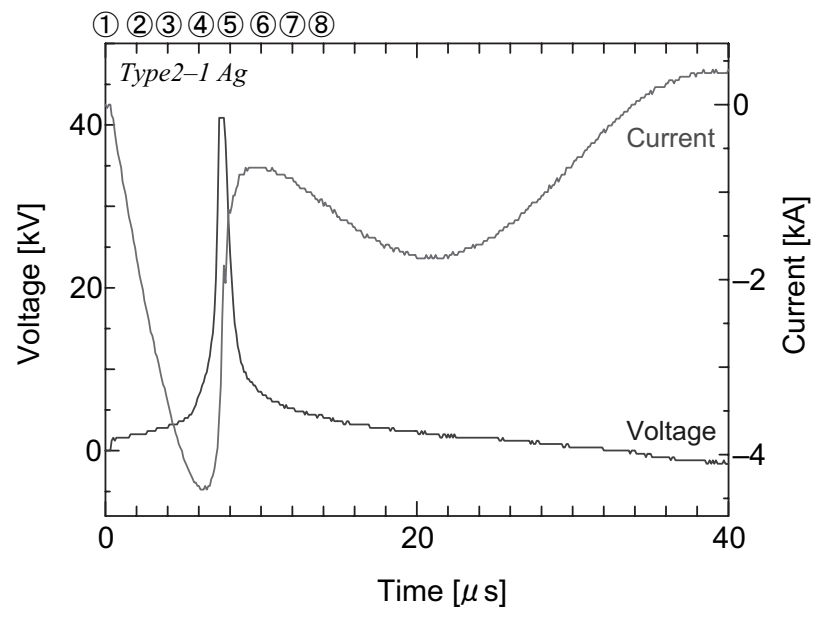

(a) Ag element

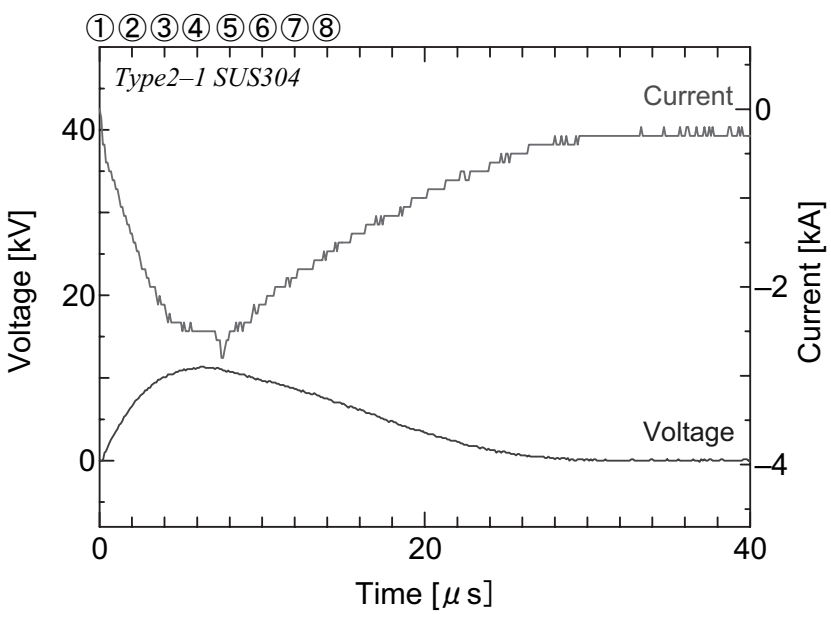

(b) stainless steal wire

Fig.7 Voltage and current waveforms in (a) Ag element, (b) Stainless steal wire.

過後の撮影写真で発光が鮮明に確認できる最初のコマであ り図 7(b) の電圧及び電流波形に扔ける電流波形のピーク值 と一致することからエレメント部の溶断が行われたことが 確認できる。試作したステンレス線を用いた模擬ヒューズ は, $\mathrm{Ag}$ エレメントを用いたヒューズと比較して同様の遮断 性能を得ることが分かった。

\section{2 遮断試験結果}

図 8 にTYPE (2) を用いた遮断試験におけるヒューズ端子 間電圧及び電流の時間変化を示す。この場合，ステンレス 線として $\phi \mathrm{s}=0.1 \mathrm{~mm}$ の細線を用いており $\phi \mathrm{p}=0.5 \mathrm{~mm}, \mathrm{lp}=$ $100 \mathrm{~mm}$ である。同図 (a) 及び (b) はコンデンサの充電電圧 $(\mathrm{V} c o)$ が $22.5 \mathrm{kV}, 37.5 \mathrm{kV}$ であり波形上側が端子電圧, 下側が電 流波形を示す。 $\mathrm{Vco}=30 \mathrm{kV}$ の際は $22.5 \mathrm{kV}$ と同様の波形 を得られた。通常のヒューズの溶断過程では通電開始後, 通電電流によってヒューズエレメントはジュール熱で加熱 


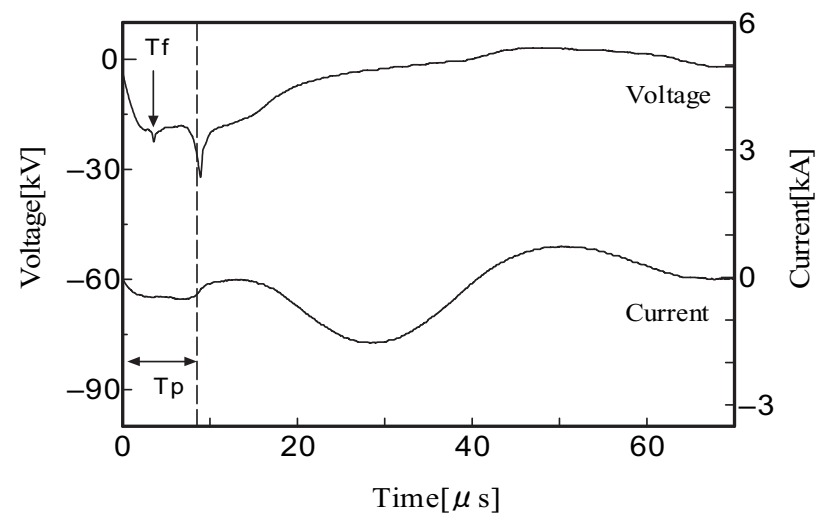

(a) $\mathrm{Vco}=22.5 \mathrm{kV}$

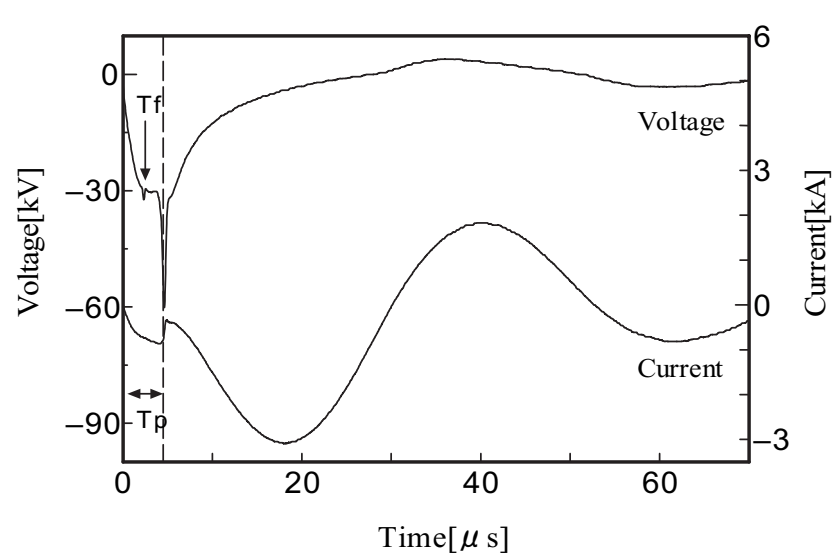

(b) $\mathrm{Vco}=37.5 \mathrm{kV}$

Fig.8 Voltage and current waveforms of Type(2) in $0.1 \mathrm{~mm}$ wire fuse with PTFE tube without arc extinguishing sand in (a) $\mathrm{Vco}=22.5 \mathrm{kV}$, (b) $\mathrm{Vco}=37.5 \mathrm{kV}$.

される ${ }^{14)}$ 。通電開始から溶融開始（以下，Tf）までが溶融 時間（以下， $\mathrm{Tm}$ ) であり、この時間間隔においては、ステ ンレス線そのものが溶融していく過程の時間である。また、 通電開始から発弧までの時間が溶断時間（以下, Tp)である。 同図 (b) のように, 印加電圧すなわち注入エネルギーを上 昇させると溶断時間は短くなる。この領域における現象は, Exploding wires phenomenon ${ }^{15)}{ }^{16)}$ と呼ばれて多くの研究が行 われている。また, 東京電機大学の荒井氏により大電流に おける銅線の破壊において破壊現象として報告されている 17)。本研究に使用しているステンレス線は, 複合金属のた め一概には文献 (17) とは同様ではない。図 9 にTYPE (2) の模擬ヒューズに消弧砂を封入した際の電圧及び電流の時 間変化を示す。図 8 と比較して, 印加電圧によって著しい 電圧及び電流波形の変化が確認できる。同図 (a)では, 図 8 の場合と異なり消弧砂の吸熱効果によって Tp を超えてか ら電流值が 0 A に減少している。同図 (b) 及び (c) は, 電流 波形が $\mathrm{Tf}$ 直後の急激な端子電圧上昇により減流し始め最大 值を過ぎた時点で発弧しており, 一度電流が $0 \mathrm{~A}$ 近くまで

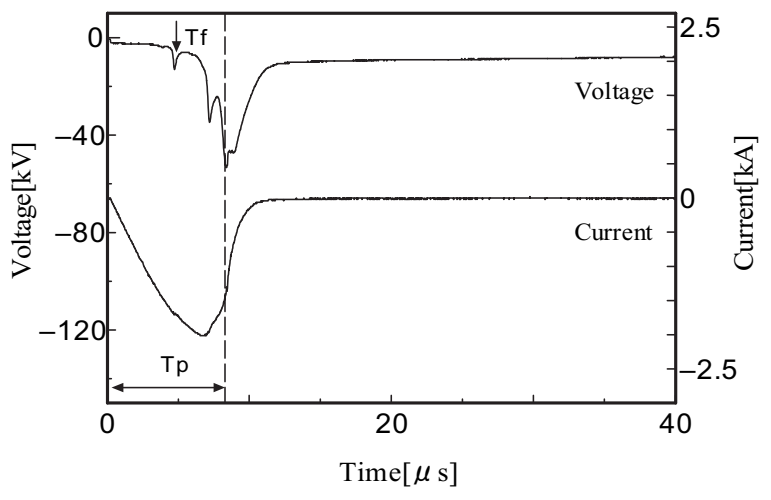

(a) $\mathrm{Vco}=22.5 \mathrm{kV}$

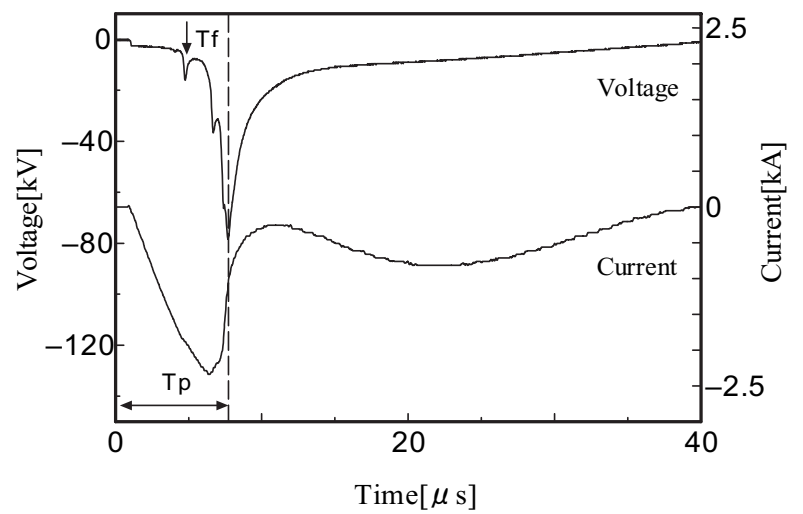

(b) $\mathrm{Vco}=30.0 \mathrm{kV}$

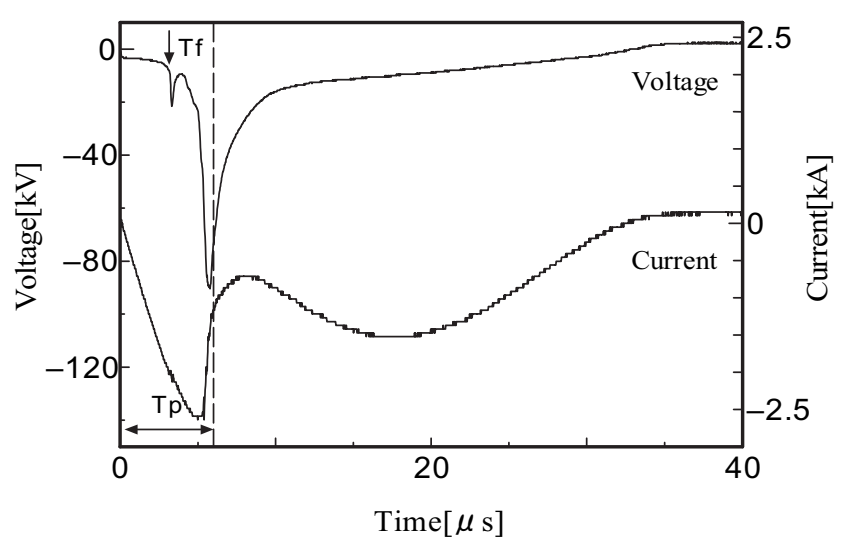

(c) $\mathrm{Vco}=37.5 \mathrm{kV}$

Fig.9 Voltage and current waveforms of Type(2) in $0.1 \mathrm{~mm}$ wire fuse with PTFE tube and arc extinguishing sand in (a) $\mathrm{Vco}=22.5 \mathrm{kV}$, (b) $\mathrm{V} c \mathrm{co}=30.0 \mathrm{kV}$ (c) $\mathrm{Vco}=37.5 \mathrm{kV}$.

減少した後, 再度電流值が上昇している。電流が $0 \mathrm{~A} に$ に近 づき電流波形において振動現象が確認することができる。 これは限流ヒューズの限流作用 ${ }^{18)}$ と式 (1)のようにアーク の消弧過程は，アークが奪われるエネルギー $\mathrm{P}_{\mathrm{d}}$ が消弧砂へ の熱伝達と溶融作用が主体をなすと考えられ上記の現象が 生じる。また，溶断が終了して発弧に達する時点の電圧波 形のピーク值は, 印加電圧が低い同図 (a)の值 $(\fallingdotseq 55 \mathrm{kV})$ 
と印加電圧が高い同図 (c) の值 $(\fallingdotseq 90 \mathrm{kV})$ では, 約 $35 \mathrm{kV}$ のピーク值の差が生じていることが確認できる。通常, Tp の発生したアークは，周囲の消弧砂を加熱しながらアーク 自体はエネルギーを失って冷却されて導電性を失う ${ }^{19}$ 。ここ こで $\mathrm{K}_{\mathrm{gas}}$ はアークが点弧する気体に関する定数, アーク抵 抗を Rとする。

$$
\frac{1}{R} \frac{d R}{d t}=K_{\text {gas }}\left(P_{d}-R i^{2}\right)
$$

ヒューズエレメント部の溶断後の消弧チューブは, 中央 部がわずかに溶融していることが目視にて確認できた。こ れは, 消弧チューブとステンレス線の隙間が構造上小さく， 大電流によりステンレス線の中央部（エレメント 1 本分） で効率良く加熱され溶融されたものと考えられる。一般に 金属線を溶融爆発させた場合は, (1)固体状態における温度 上昇，(2)融点に達した後の溶融過程，(3)液体状態における 温度上昇, (4)沸点に達した気化後, アークを発生して4 段 階の状態変化を経て金属は溶断されると言われている ${ }^{19}$ 。 試作した模擬ヒューズは, ステンレスエレメントに通電開 始後, ジュール熱により固体状態での温度上昇が生じて融 点に達する。その後, ステンレスエレメントは溶融して液 化して温度上昇する。その後は, 沸点に達して最終的に気 化して 4 段階の状態変化を経てヒューズの遮断に至ったと 著者らのこれまでの研究結果 ${ }^{20)}$ と総合して考えられる。更 に, ステンレスエレメントの温度が上昇して, 溶融から蒸 発して, 破断することも考えられる。また, 実験結果の電 流值を見ると, $\mathrm{kA}$ オーダの電流が直径 $1 \mathrm{~mm}$ 以下のステンレ スエレメントに流れているため, 電流密度が高く, 大きな 電磁ピンチ力も働くものと考えられる。つまり, ジュール 熱でステンレスエレメントが溶融し、液体になると、電磁 力で切れる可能性もある ${ }^{21)}$ 。実際には，ヒューズ遮断後の アクリルパイプ内面には, 消弧チューブの溶融後のすす等 の残存物が見られる。

図 10 に TYPE (2) ヒューズの Tm と印加電圧（以下，V) との関係 (以下, $\mathrm{Tm}-\mathrm{V}$ 特性) を示す。 Tm- $\mathrm{V}$ 特性は, 消 弧チューブ内の加熱特性が消弧チューブの内径に左右され ることを示している。眓中に扔いてはそれぞれ3 個分のア ンサンブル平均值を示して㧍りム印（アクリル製パイプ内 に消弧砂なしの場合）及び $\triangle$ 印（アクリル製パイプ内に消 弧砂を封入した場合）は $\mathrm{lp}=80 \mathrm{~mm}$, 口印（アクリル製パ イプ内に消弧砂なしの場合）及び $\square$ 印（アクリル製パイプ 内に消弧砂を封入した場合）は $\mathrm{pp}=100 \mathrm{~mm}$ とている。同 図より模擬ヒューズが溶断した後に，消弧砂をアクリル製 パイプ内に封入していない場合の模擬ヒューズの溶断時間 は，封入した場合よりも短い。これはヒューズエレメント が消弧砂に接していると熱が散逸しやすいためにこのよう な効果が生じたものと考えられる。

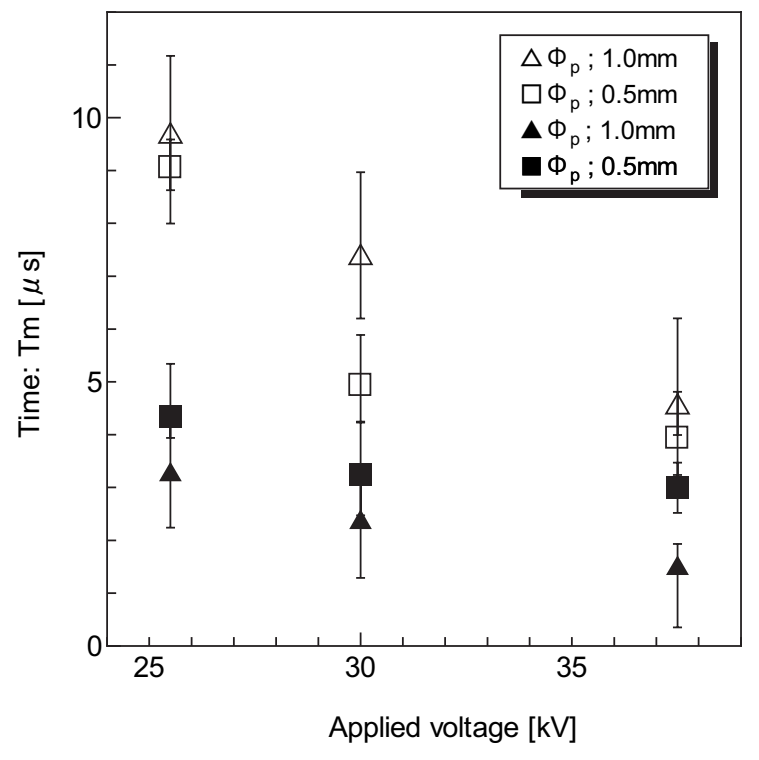

Fig.10 Relation between applied voltage and breaking time.

\section{3 遮断時騷音の検討}

騒音問題等から環境を考慮した配電機器の開発を目的と して, 模擬ヒューズに扔けるヒューズ溶断時の最大騒音（最 大值の平均) 特性を調べた。印加電圧 (コンデンサ充電電圧) を $22.5 \mathrm{kV}, 30.0 \mathrm{kV}$ 及び $37.5 \mathrm{kV}$ とした。3 種類の模擬ヒュー ズを使用し，TYPE (1)に扮ける騒音特性（以下， Open）, TYPE (2)に扔ける騒音特性 (Without Sand) 及び TYPE (2)に 消弧砂を封入した場合 (With Sand) とした。また, ヒュー ズを使用しない場合を想定して遮断試験回路の短絡スイッ チ $(\mathrm{Sw})$ を ONにする際に発生する機械的騒音強度（以下, Switch）を測定して騒音特性を図 11 に示す。同図より印 加電圧 $22.5 \mathrm{kV}$ の場合, Openでは $110.6 \mathrm{~dB}$ の騒音強度に 対してWithout Sand においては, $81.6 \mathrm{~dB}$ であり With Sand に打いては $77.0 \mathrm{~dB}$ であった。また, Switchの騒音強度は $72.2 \mathrm{~dB}$ であった。消弧砂を使用した場合の騒音は, 遮断試 験の短絡スイッチ音と変わらなく非常に小さい騒音強度で ある。消弧砂は試作したヒューズに掞いて十分に消弧機能 が作用しており遮断時の騒音を抑制することが確かめられ た。

\section{4. むすび}

現在使用されている $\mathrm{Ag}$ ヒューズエレメントよりもコロ ナ放電耐性に優れ, 構造が簡単な高圧カットアウト用限流 ヒューズを試作した。試作した模擬ヒューズにおける遮断 試験を行い，模擬ヒューズの遮断特性を検討した。主な結 果をまとめると以下の通りである。

（1）遮断試験において消弧砂がある場合には，ヒューズ遮 断時間が短く, 溶断後約 $20 \mu \mathrm{s}$ でアーク電流は $0 \mathrm{~A}$ に 近づく。 


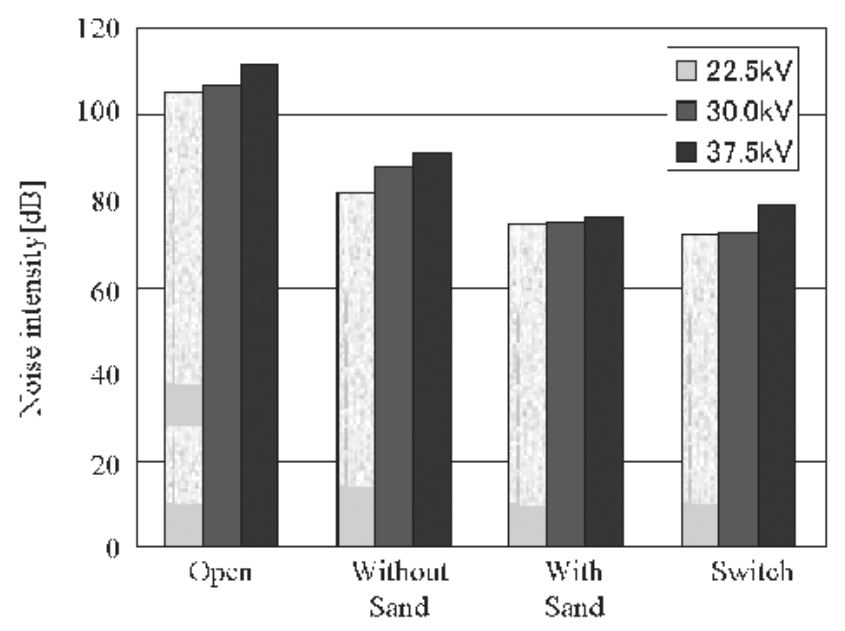

Fig.11 Noise intensity.

（2）遮断試験におけるヒューズ遮断時間は, 消弧砂を封入 すると遮断時間は短くなる。

（3）消弧砂を模擬ヒューズに用いた場合, ヒューズの遮断 時の騒音強度は消弧砂を使用していない模擬ヒューズ よりも小さい。

（4）意図的に設けたヒューズエレメント部の中央の間隔は, 確実にヒューズ中央部で溶断するための機能に寄与す る。

（5）振動性インパルス大電流印加時にヒューズエレメント は中央部で溶断を開始することが発光から確認でき る。

今後は, $\mathrm{AC}$ 電圧重畳実験特性を明らかにして実際の 22 $\mathrm{kV}$ 級高圧カットアウト用ヒューズとして実用化を検討す る。

本研究の一部は, 平成 14 年度 日本学術振興会科学研究 費補助金基盤研究 (C) (2) (No.13650314)の助成を受けたこ とを記し, 実験にご協力頂きました牧 賢治氏（九州電力 $($ 株)，冨永直樹氏（東京電力(秼)）及び年見義秀氏（富士電機 システムズ(株) 関係各位に謝意を表します。

\section{参考文献}

1) 加藤敏夫 - 砂辺欣也：「高圧カットアウトの大電流しゃ断特 性（その 2) - 配電近代化赤城実験場内 $6.6 \mathrm{kV}$ 配電線の再起電 圧特性 - 」, 電力中央研究所報告, No.780002, pp.1-33 (1981).

2) 大坪昌久 - 高田寿久 - 松根泉樹 - 本田親久 $\cdot$ 福井康博 : 「高 圧カットアウト用ヒューズのコロナ放電による劣化特性と分 析」, 電気学会放電研究会資料, ED-99-6, pp.29-34 (1999).

3) 大坪昌久.湯地敏史·冨永直樹·年見義秀·本田親久. 牧 賢治: 「ステンレス線を用いた低コスト高圧カットアウトヒューズ の開発」, 第 19 回電気設備学会全国大会, G-3, pp.403-404 (2001).
4) 高田寿久·岩元秀樹 · 大坪昌久·本田親久·牧 賢治 : 「 $22 \mathrm{kV}$ 高圧カットアウトヒューズの劣化原因の解明とステンレス線 を用いた限流型ヒューズの開発」, 宮崎大学工学部紀要, 第 30 号別冊, pp.189-194 (2001).

5) 柿本·鎗光・宇津宮・山田: $\lceil 22 \mathrm{kV}$ 半限流型カットアウトヒュー ズの開発」, 平成 11 年度電気学会電力.エネルギー部門大会, No.478, pp.419-420 (2000).

6) 松岡正憲・荒井聰明：「アークによるプラスチックチュー ブの消耗質量に関する検討」, 電学論, Vol.118-B, No.12, pp.1380-1385 (1998).

7) T.Yuji, S.Hidaka, M.Otsubo, C.Honda, and K.Maki: "Characteristics of New Type Current-limiting Fuse using Stainless Steel Wire", 2002 Joint Conference of ACED \& K-J Symposium on ED and HVE, pp.672-675 (2002).

8) 高田寿久 · 冨永直樹 - 岩元秀樹 $\cdot$ 大坪昌久 - 本田親久 $\cdot$ 福井 康博：「各種ヒューズエレメント材料の溶断試験とコロナ放 電による劣化特性」, 平成 12 年度電気関係学会九州支部連合 大会論文集, No.609, p.243 (2000).

9) 荒井聰明 - 加藤敏夫 :「高圧カットアウトの負荷開閉と動作」, 電気学会開閉保護装置研究会資料, SPD-80-7, pp.11-20 (1980).

10）稲葉次紀・石川忠夫：「限流しゃ断装置の基礎特性（第 6 報） 一水冷エレメントによる高速直流しゃ断特性 - 」, 電力中央研 究所報告, No.181047, pp.1-73 (1982).

11）長田正義・横井良秀：「衝撃電流による金属線爆発時の溶融 過程のエネルギー」, 電学論, Vol.93-A, No.7, pp.285-289 (1973)

12) 稲葉次紀・葛間泰邦・合田豊：「複合抵抗転流式直流負 荷遮断器の基本原理と遮断特性」, 電力中央研究所報告, No.683001, pp.1-51 (1983).

13) 稲葉次紀：「液体窒素中に扔ける水平銅線の最小溶断電流と その影響因子」, 電学論, Vol.99-A, No.3, pp.97-104 (1979).

14）稲葉次紀：「直流限流ヒューズの基本特性（第 2 報）- 液体 $\mathrm{N}_{2}$ 中エレメントの溶断特性 - 」, 電力中央研究所技術第一研究 所報告, No.74705, pp.1-45 (1975).

15) W.G.Chace \& H.K.Moore editing: Exploding Wires (Books), VOLUME2, PLENUM PRESS (1962).

16) W.G.Chace \& H.K.Moore editing: Exploding Wires (Books), VOLUME3, PLENUM PRESS (1964).

17) 荒井聰明 : 「大電流による細い銀線の破壊」, 電学論, Vol.91, No.11, pp.123-132 (1971).

18) 電気学会ヒューズ専門委員会：「ヒューズの溶断時間と限流 ヒューズの最大アークエネルギーについて」, 電気学会技術 報告（II 部），第 7 号，pp.1-60 (1970).

19) 法貴四郎・藤 幸生 :「衝撃電流による導線の溶融站に気化」, 電学論, Vol.664, No.63, pp.838-840 (1944).

20) 高田寿久·岩元秀樹・大坪昌久・牧 賢治：「各種ヒューズ エレメント材料の溶断試験と限流ヒューズの開発」, 電気学 会放電研究会資料, ED-01-29, pp.65-70 (2001).

21）胡 小博・田代真一 - 岩尾徹・稲葉次紀：「インパル ス大電流による直線銅線の破断特性及び電磁力影響」, 平 成18年電気学会全国大会講演集（CD-ROM），No.6-198， pp.336-337 (2006). 